\title{
A Review on Hereditary Qualities Assorted Variety of American Cotton
}

\author{
Umer Farooq1, Jawad Amin'2, Muhammad Qasim², Muhammad Ismail1, Umair Majeed1, \\ Muhammad Ahtisham Tahir ${ }^{3 *}$, Hasnain Haider ${ }^{1}$, Waqar Hussain ${ }^{4}$, Muhammad Imran ${ }^{1}$ \\ ${ }^{1}$ Department of Plant Breeding and Genetics, Bahauddin Zakariya University, Multan, Pakistan \\ ${ }^{2}$ Department of Agronomy, Muhammad Nawaz Shareef University of Agriculture, Multan, Pakistan \\ ${ }^{3}$ Department of Plant Breeding and Genetics, University of Agriculture, Faisalabad, Pakistan \\ ${ }^{4}$ Department of Agronomy, University of Agriculture, Faisalabad, Pakistan \\ Email: *ahtishamtahir93@gmail.com
}

How to cite this paper: Farooq, U., Amin, J., Qasim, M., Ismail, M., Majeed, U., Tahir, M.A., Haider, H., Hussain, W. and Imran, M. (2018) A Review on Hereditary Qualities Assorted Variety of American Cotton. Agricultural Sciences, 9, 587-608.

https://doi.org/10.4236/as.2018.95041

Received: February 5, 2018

Accepted: May 28, 2018

Published: May 31, 2018

Copyright (C) 2018 by authors and Scientific Research Publishing Inc. This work is licensed under the Creative Commons Attribution-NonCommercial International License (CC BY-NC 4.0). http://creativecommons.org/licenses/by-nc/4.0/

\begin{abstract}
Cotton is an economically important natural fiber in the world, whose seeds are used as food and fiber used in the manufacturing of textiles. Cotton is naturally a renewable synthetic fiber which is derived from petroleum. Restriction in conventional breeding program to hereditary change may be because of those of information something like yield revenue and fiber quality of traits. Vitally, the genome representation of the cotton for various traits is the basic need for breeding purposes. The present review discusses the issues of conventional breeding and genomics resources \& efforts are utilized to enhance the yield of cotton.
\end{abstract}

\section{Keywords}

Cotton, Genetic Diversity, QTL, MAS, RFLP, SSR, SNP

\section{Introduction}

Cotton belongs to genus Gossypium and family Malvaceae. Gossypium consists of $45-50$ species, with $40-45$ being diploids $(2 \mathrm{n}=26)$ and 5 being allotetraploids $(2 \mathrm{n}=52)$. Globally the cultivated cotton is one of the most vital crop which produce the natural fiber that is used in the textile industry and is the $2^{\text {nd }}$ most vital oilseed crop. Seed hairs, which are significant single cells, range from 30 to $40 \mathrm{~mm}$ in length and $15 \mu \mathrm{m}$ in thickness mostly in cultivated species. Cotton fiber is a brilliant model structure for studying plant cell advancement. The most extensively used method is random amplified polymorphic DNA (RAPD) technique for researching in cotton which has been reported by [1] [2] 
[3] [4]. Cotton is not only for the textile fiber and oilseed crop globally, but it also gives a worth for foil energy and bioenergy production. The native of cotton is in tropics and subtropics naturally which include the America, Africa and Asia. About in 100 countries cotton is cultivated. China, India, USA and Pakistan are in top of growing cotton, about $2 / 3$ of the world's cotton.

\section{Development in Cotton}

Genome research plays a vital role in the development and enhancement of genetic improvement of cotton. Consequently, efforts have been made for the development of genomic resources and tools for simple and applied genetics.

Modern technologies are supposed to be the one who will increase the crop productivity and income. But, it demands more investment, and this is a crucial factor, to implement modern technologies. As like, the use of Genetically Modified (GM) seeds in various areas of the world. In Pakistan the GM BT cotton seeds are most commonly used. The GM seeds, reduces the use of pesticide and gives higher productivity in the world [5] [6]. However, the implementation of BT seeds requires financial resources and availability to farmers for different actions from sowing to harvesting. In Pakistan, the earlier studies show that the factors which are related to increase the productivity of cotton, helps the cotton growers to earn more [7] [8].

Analyses of genetic diversity also include many species of cotton. The success rate is high in modern technologies but all in vain because of the low level of polymorphism, with RFLP markers having predominantly low intraspecific and interspecific polymorphism [9]. In the studies of cotton genetic diversity, these microsatellites markers are polymorphic, codominant and based on the polymerase chain reaction (PCR) [10], In excess of 1000 microsatellites primers, these are isolated from cotton genome libraries [11].

To comprehend the hereditary decent variety of cotton which is portrayed in US national cotton germplasm collection is essential to give a course in collecting, protecting and applying these germplasm assets [12] [13].

In genetic enhancement, the handiest efforts are used for the cultivated tetraploid species $G$. hirsutum and G. barbadense occur in the primary gene pool [14]. G. hirsutum and G. barbadense constitute about $75 \%$ of the content of USA of Agriculture's National Cotton Germplasm Collection (NCGC). Efforts are made to define and categorise the diversity of these species in NCGC to precede genetic analyses and initiated with the collection of phenotypic data using descriptors [15] [16] [17].

Though, a current genetic assessment with simple sequence repeat (SSR) markers of germplasm from the CIRAD group maintained the survival of 7 races [18]. Great no of genetic collections were recognised and suggestions were made which is based in the breeding history and pedigrees comparatively country of origin. 
Some studies have described different characteristics of genetic diversity of upland cotton in NCGC, usually in small number of markers and cultivar [19] [20]. There are some reports on the molecular analyses which concentrated on G. barbadense genetic diversity and also on the G. hirsutum. Initial studies are used for isozymes to evaluate the genetic and source of the G. barbadense accessions, mainly from the NCGC [21].

This study shows that the geographic collections and recommended north-western South America for species is the center of diversity. Four characteristics describe the improvement in the G. barbadense accessions: Four categories were proposed describing the continuum of improvement observed in $G$. barbadense accessions: 1) wild, 2) dooryard, 3) landraces, and 4) improved modern cultivars [22] [21].

In (1990) Percy and Wendel also analyzed the 63 accessions of DNA-based markers. About $27.1 \%$ of G. barbadense and $24.5 \%$ of the G. hirsutum accessions of NCGC are existing in the GDRS. In tertraploid species the set of markers are separating interspecific variation and intra-genome variation that has been reported earlier within the context of all genomes [23]. Though, a wide and extra inclusive studies of relationships, and genetic diversity structure of these viable tetraploid species, as characterised in the NCGC is assured in view of the fact that they establish over $98 \%$ of the world's viable production.

DNA marker systems for germplasm genotyping must be accurate, highly informative, amendable to automation, and cost-effective

Simple sequence repeats (SSRs) are considered to be ideal and friendly tools for such studies as they are polymerase chain reaction (PCR)-based markers, genetically defined, typically co-dominant and uniformly dispersed throughout plant genomes [24] [25].

\section{Economic Importance of Cotton}

1) Pakistan is one of the most important cotton and yarn producing country and advancing their force in the global cotton and textile market place. Still, Pakistan has to expand the capacities of cotton promotion and quality control in order to achieve this aim. For the agrarian economy, cotton occupies a sole position in the country.

2) Pakistan become a key player in the global cotton and textile market place, if it focuses more on the research programs but now, the government has been giving importance to research and developmental programs both on the qualitative and quantitative for the advancement in cotton.

3) In Pakistan cotton is a central cash crop for the most of farmers and is also known as "white gold". It is annually cultivated over 3.2 million hectares and occupies 13.9 percent of the crop area in the country. Averagely, it contributes 21.9 percent of the worth added by major crops. Punjab is the central producer of cotton, occupies 80 percent of its area and gives 76.8 percent of the production. (Sindh) holds the 19 percent area and 22 percent in production. 
4) In 2016-17, world cotton production amounted to 23.2 million metric tons. However, the growth rate was slow during the mid of 1990s, production continued its rising tendency during the era. The value of world cotton export unit normally in 2000 was estimated about US $\$ 26.6$ billion.

5) In the world market, cotton is the important product traded for both in terms of value and volumes. In 2000, the countries which were importing the cotton probably 100 and of which 85 were developing countries. And also, in 2000 the revenue for world export from cotton was US $\$ 7.1$ billion. The revenue of global exports gives only 2.1 percent from all agricultural products.

6) Cotton is the most important textile fiber in the world. In addition, 80 nations from over the world create cotton, the China, United States, India together give half of the world cotton. Similarly Pakistan is also called as ancient homes of cultivated cotton. Ranking of Pakistan with respect to cotton consumption in the world is shown in Figure 1.

7) In Pakistan 1.3 million farmers cultivated the cotton over 3 million hectares. Cotton contributes about 10.7 percent to GDP and 54.7\% to foreign earnings. Taken overall, in the proximity of 30 and 40 for every change of the cotton winds up as residential utilization of conclusive items. The remaining is sent out as crude cotton, yarn, material, and articles of clothing.

8) Cotton has received high preference in Pakistan. Cotton creation reinforces Pakistan's greatest mechanical fragment, including some place in the scope of 400 material plants, 6.9 million spindles, 27,000 weavers the production line zone (tallying 15,000 shuttle less weavers), 250,000 weaving machines the non-process section, 700 knitwear units, 4000 piece of attire units (with 200,000 sewing machines), 650 shading and finishing units (with finishing farthest point of 1150 million square meters for consistently), around 1000 ginneries, 300 oil expellers, and 15,000 to 20,000 indigenous, little scale oil expellers.

9) The prime objective to develop a new cultivar which has resistant to pest,

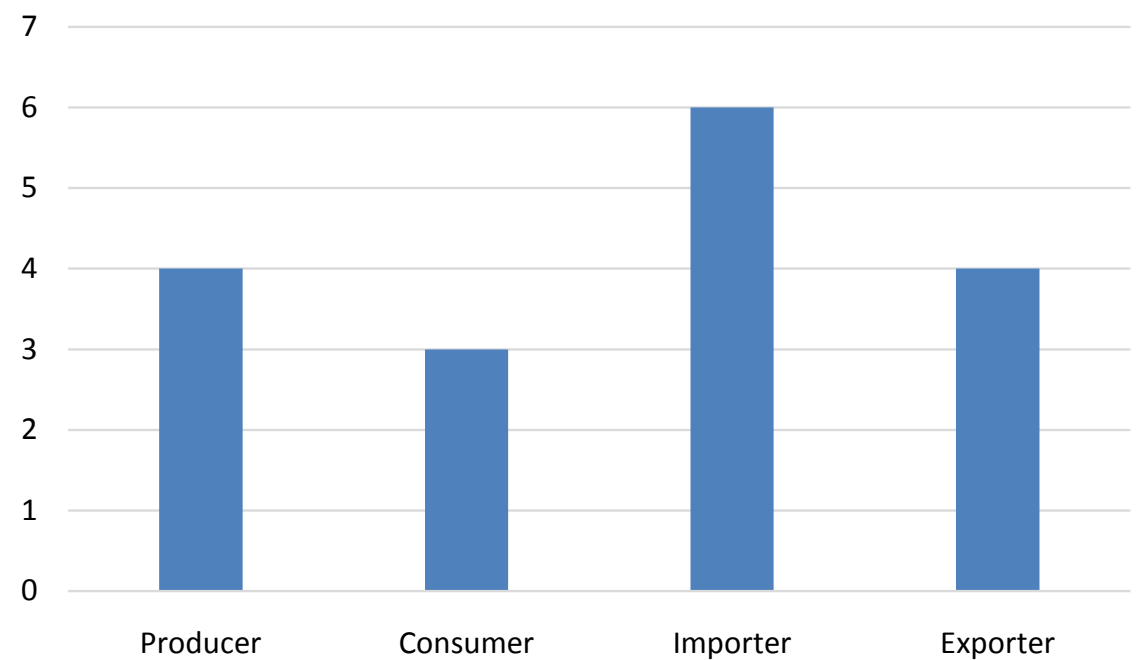

Figure 1. Ranking of Pakistan with respect to cotton consumption in the world. 
drought and heat tolerant, and also have the attractive fiber quality traits. Although from countless research sweats, Pakistan endures huge economic failures being constant pest attacks on the crop. Around 10\% - 15\% in a classic year to 30 40 in an out crop year [26].

10) It is by any measure Pakistan's most vital financial segment. As anyone might expect, government approach has for the most part been utilized to keep up a stable and frequently generally low domestic cost of cotton, particularly since 1986-87 through the inconvenience of fare obligations, with a specific end goal to help local industry.

\section{Problems of Cotton}

Cotton supervision in composite undeveloped organizations is inclined by time clashes in the harvesting of former crops and the sowing of cotton and connections due to remaining effects on following crops [27] [28] found that appropriate availability of inputs such as seed, compost, weedicides and insecticides could enhance crop yield. There are many reasons that effect cotton yield. They consist of somatic factors such as land preparation, seed, irrigation, plant safety measures, etc. and qualitative variables like education, age, farming experience, etc.

\subsection{Education}

Education displays a dynamic part in the acceptance of improved technology and achieving higher productivity level. The educated farmers accomplish various farm practices in an improved way as compared to uneducated farmers and they learn simply about new expansion and innovation regarding production knowledge of crop [29] [30].

\subsection{Seed Rate}

Assumed the additional issues, seed rate decides the plant population in a field of certain crop as a result, is an important aspect in determining yield. The coefficient of seed rate was positive, however, it was statistically non-significant. It might be due to the fact that the farmers were consuming seed according to recommended level.

\subsection{Irrigation}

Cotton is a deep-rooted crop and the properties of extreme or fewer irrigations are not observable immediately. The farmers have to be very watchful while applying irrigations which depend upon the rate and structure of irrigation. Overall crop water requirement is 35 - 45 inches to get a satisfactory yield. The most acute periods for irrigation are early flowering to first boll opening and maturity.

\subsection{Practice of Fertilizers}

The recommendations about use of chemical fertilizers to cotton crop also high- 
light the use of balance dose of fertilizers (N:P:K). Therefore, variables of $\mathrm{P}$-nutrients and $\mathrm{N}$-nutrients were involved in the model. The coefficients of nitrogen nutrient and phosphorus nutrient were positive and were statistically significant at $5 \%$ probability level. The outcomes exhibited that the additional use of fertilizer contributed to higher yield and the cotton growers could improve their crop production by applying applicable combination of N:P:K.

\subsection{Protection of Plant}

Plant protection dealings include weeding, hoeing and use of pesticide to control pest and disease on cotton crop. The rate of weeds, pests and disease on cotton crop is a rising problem in all cotton-growing zones of Pakistan and implementation of chemical control methods are progressively becoming popular between the cotton growers. The outcomes of the production purpose reveal that cost of plant protection measures had a positive coefficient (0.244) and it was statistically highly significant.

\subsection{Progress of Branches}

The branches on a cotton plant can be categorised as also vegetative branches (monopodia) or fruiting branches (sympodia). Like the main stem are mentioned to as monopodia (meaning "single foot") Vegetative branches, since they have only one meristem. As vegetative branches have only one meristem, like the main stem they grow straight and erect. Fruiting branches are produce by Vegetative branches.

\subsection{Climate}

Cotton is a tropical plus subtropical crop and its cultivation is limited up to an altitude of $1000 \mathrm{~m}$ from sea level. Cotton is a long day crop. Seed growth takes place when average temperature range is $16^{\circ} \mathrm{C}$ and Cotton is satisfactory at 430 $\mathrm{C}$ of vegetative growth. It is a warm season crop and matures well in areas having annual rainfall of $50 \mathrm{~cm}$ with heavy showers at the time of ball formation.

Cotton is very subtle to variations in atmospheric temperature and rainfall. At the time of sowing a very low temperature below $16^{\circ} \mathrm{C}$ results in poor germination, however high temperature results in etiolation (falling of buds) and poor crop-stand. In the period of plant growth, humid and warm climate is favourable for pests, insects and diseases that cause more damage to quality and quantity of its fiber.

Heavy rains and immobile water is injurious at all the stages of its development. The boll shedding appears by heavy rain during fruiting stage.

\subsection{Disease of Cotton}

Cotton leaf curl (CLCuV) Gemini virus causes a main disease of cotton in Asia and Africa. Leaves of infected cotton curl upward and leaf like enations on the base along with vein thickening. In the early season infected plants are stunted 
and yield is severely reduced. Severe increase in of CLCuV have occurred in Pakistan in the past few years, with yield losses as high as 100\% in fields where infection occurred early in the growing season.

Whitefly transferred the virus of disease. The first signs of infection in cotton appear within 2 - 3 weeks of inoculation and are initially characterised by deep downward cupping of the newest leaves.

\section{Fiber Traits of Cotton}

\subsection{Fiber Length (FL)}

The contribution of Fiber length exhibited positive effect (3.239) towards seed cotton yield at Khanewal while negative effects $(-0.218)$ at Multan. The negative secondary effects for fiber strength at both Multan and Khanewal locations while the secondary positive effect of fiber length was found for upper half means length.

The negative secondary effects for GOT percentage, fiber length, micronaire value and mean length only at Multan location whereas the secondary positive effects were observed for fiber uniformity index. The negative secondary effects for fiber uniformity index only at Khanewal location whereas the positive secondary effects of fiber length on seed cotton yield were observed for GOT percentage, fiber length, micronaire value, mean length and upper half means length. Similarly the consequences were also stated by Thiyagu et al. stated that staple length had a positive straight effect on seed cotton yield consequences were detected at Multan location.

In similarity to Khanewal location [31], in their study on seed cotton yield also resolved that fiber length had negative straight effects.

\subsection{Fiber Strength (FS)}

Fiber strength exhibited negative straight effects $(-4.126)$ at Khanewal whereas positive straight effects (0.798) to seed cotton yield at Multan location. Both at Multan and Khanewal locations the secondary positive effects were recognized for micronaire value, mean length and GOT percentage. The positive secondary effects were found for fiber uniformity index at Multan.

The positive secondary effects were recognized for upper half mean length and fiber length at Khanewal while these traits exhibited negative exhibited effects at Multan location [31]. Also found related results some other scientists noted that on seed cotton yield fiber strength had positive straight effect. On seed cotton yield the staple strength had positive straight effect recommended by Wright.

\subsection{Micronaire Value ( $M N)$}

As the positive straight effects $(0.265)$ were presented by micronaire value for seed cotton yield at Multan while negative straight effects $(-0.421)$ at Khanewal location. Micronaire value represents negative secondary effects of GOT per- 
centage at both Multan and Khanewal locations while positive secondary effects of fiber strength.

At Multan location the secondary positive effects were recognized for fiber strength, fiber length and mean length. The secondary effects were recognized for fiber length, upper half and mean length at Khanewal only. Early scientists noted that the fiber fineness is straightly affect seed cotton yield.

Some other scientists noted related consequences in reference to Khanewal. The positive and secondary effect of fiber fineness on seed cotton yield noted by [32].

\subsection{Mean Length (ML)}

On seed cotton yield mean length exhibited positive straight effects (0.006 and 1.165) at Multan and Khanewal. At both Multan and Khanewal the positive secondary effects of mean length on seed cotton yield were recognized for fiber length.

The negative secondary effect was recognized for GOT percentage, micronaire value and upper half mean length while positive secondary effects were recognized for fiber strength and fiber uniformity index at Multan site only and these traits exhibited positive secondary effects at Khanewal site.

\subsection{Upper Half Means Length (UHML)}

On seed cotton yield the upper half means length exhibited positive straight effects $(1.207)$ at Khanewal while negative $(-0.529)$ at Multan. The secondary negative effect was shown for fiber strength while the secondary positive effects were found for GOT percentage at both Khanewal and Multan sites.

The negative secondary effects were exhibit by micronaire value and mean length at Multan site while these traits exhibited positive secondary effects at Khanewal site.

\subsection{Fiber Uniformity Index (FU)}

On cotton seed yield the positive straight contribution was recognized by fiber uniformity index (0.06) at Multan while the negative straight effects (-0.65) were noted at Khanewal site. The uniformity index of fiber positive effects for micronaire value, fiber length and GOT percentage at both Multan and Khanewal locations.

The uniformity of fiber which exhibit positive effects were recognized on seed cotton yield for fiber strength while negative effects were recognized for upper half and mean length mean length at Multan site only. The upper half mean length and mean length at Khanewal site exhibited positive effect while negative effect was observed for fiber strength. Wrigth reported that the results are similar of Multan site to Khanewal site.

\subsection{Lint Percentage}

Polygenic is a complex trait in Lint percentage (ginning outturn) which is 
mainly affected by the environmental factors. Predominantly, cotton seed has a straight effect on yield, it depends on lint weight. For the increase in higher ginning outturn of Cotton the Selection is based on the production per plant and per unit area. [33] for the average eight cultivars the lint \% was recorded from $37.28 \%$ to $40.22 \%$.

The cultivar SLH-279 has the highest lint \% (38.13\%) was observed and Compared by the two other cultivars CIM-473 and CIM-496 having $37.03 \%$ and $37.42 \%$, respectively. The cultivars (CIM-446, CIM-506 and CIM-538) ranged from $35.47 \%$ to $35.72 \%$ was found balanced but cultivar CIM-707 exhibited lowest lint \% (35.17\%) [34] [35].

\subsection{Cottonseed Oil Percentage}

In current studies, among the eight cultivars of upland cotton the oil \% ranged from $27.52 \%$ to $30.15 \%$. The genotype SLH-279 has the Maximum oil \% (30.15\%) of cottonseed. The average cottonseed oil \% (27.52\% to $28.08 \%)$ exhibited by the remaining six cultivars. But the cultivar CIM-499 exhibited lowest cottonseed oil content (27.52\%) [36].

\section{Stress}

Water is a crucial source for plant growth, development and effects of plant morphology which is a critical physiological functions, the results are obvious in decreased yield, poor growth and fiber quality.

\subsection{Morphology}

- Plant height

- Fruiting points

- Root depth and proliferation

- Leaf area

- Branching

Normally, reduced boll production from less flowers and bolls [37] [38] and complete condensed leaf area and photosynthesis [39]. A positive association among yield and the number of bolls produced [40]. For the improvement in boll production and retention, irrigation plays a crucial role [41].

By the decrease of water potential, the shedding rate increases [42] and pollen sterility [43] which shows less seeds per boll and lower boll numbers. Properties of fiber are quite unresponsive to water stress, except the stress is extremely severe. The cotton fiber elongation is chiefly dependent on turgor and the leaf water potential $<-2.7 \mathrm{MPa}$ can decrease the fiber length, similarly the micronaire also decreased [44] [45] [46].

\subsection{Drought Stress}

Lengthy dry period due to uneven and unpredictable monsoon chiefly under rainfed situation will lead to quick reduction in soil moisture. It gradually 
strengthens and develops throughout the progression of soil moisture decline resulting in limited growth and development in cotton.

The present photosynthesis is reduced and sustainability of leaf turgor may not be suitable to exhibit a well-organized covering. Cotton has to familiarize or bear such antagonistic effects by many morph-physiological traits.

A physiological process which is use to hold developed water use effectiveness. By stomatal regulation, it can be achieved easily. By stomatal closure the prevention of water loss can be in the limiting active transpiration from the leaf surface.

The protective mechanism acted on the leaf surface of epicutilcular wax. The most critical crop stage is dry spell which plays a vital role. At early stage, growth may lead to poor crop position and the existence of the crop mostly is at a great risk. If the dry spell duration increases and takes more time at early growth stage may be developed as terrible for cotton performance. Mid growth stage also effects the flowering which is dangerous for yield realization. Requirement of water at this stage is relatively higher of the crop age to withstand developing young bolls and squares, but the requirement of water is lower at pre-flowering and post-flowering stages. The water necessity of cotton relating to various phases of development is given in Table 1 .

For obtaining a normal yield, the cotton water requirement is approximately 5000 to $8000 \mathrm{cu} . \mathrm{m}$. On the physiological processes, the reduced water availability due to dry spell has a prognostic effect on growth and development.

At central institute for cotton research, Nagpur shows that the leaf water potential above 13 bars is more critical. Due to the existence of fatal moisture stress, the yield on early stage may not give great contribution and it also effects on the late fruiting parts and gives meager productivity. Between all serious stages, flowering phase is significant which gives the actual contribution of developing gradually towards yield is concerned.

\subsection{Low Light Stress}

In India, the half \& full cloudy weather conditions from July to September cause low light stress which affects the growth and development of cotton. If the rainfed continues, the low light stress also exceeded. Due to the decrease in light intensity and full sunshine the stress arises.

The reaction of plants towards low-light stress arises mostly by determined increase in chlorophyll content and area for operative light interference. The yield of cotton-seed reduced in this situation. Low light adversely effects on yield

Table 1. Water requirements at different growth stages of cotton (cubic m per ha).

\begin{tabular}{cc}
\hline Crop stage & Water requirement \\
\hline Before flowering & $690-790$ \\
During flowering & $790-1000$ \\
During ripening & $600-700$ \\
\hline
\end{tabular}


and increase in stress for longer period of time. The frequency of low light in reproduction increases the shedding of fruiting parts which leads to affect the final yield. Studies showed at CICR, Nagpur that a low light stress tolerant genotypes like JBWR 20, JBWR 34, TXORSC 78, VAR 13, JBWR 2, JK 97, IC 283, LRA 5166, have higher tolerance to induced low light.

\subsection{Salinity Stress}

\subsubsection{Types of Salt Affected Soils}

Arid and semiarid regions of the world have salt affected soils. Some common ions like $\mathrm{Ca} . \mathrm{Mg}, \mathrm{Na}, \mathrm{C} 1, \mathrm{SO}_{4}, \mathrm{HCO}_{3}$ and also the $\mathrm{K}$ and $\mathrm{No}_{3}$ contributing to this issue. For alkali soils, the USDA classified the soils which have the EC of saturated extract more than $4 \mathrm{dS} \cdot \mathrm{m}^{-1}$, ESP more than 15 and $\mathrm{pH}$ more than 8.5 . Since maximum no of the crops are sensitive to salinity. The American society of soil science, recently summarized the limits for saline soils $2 \mathrm{dS} \cdot \mathrm{m}^{-1}$ from $4 \mathrm{dS} \cdot \mathrm{m}^{-1}$.

\subsubsection{Occurrence}

Almost in all agro-ecological regions the salt affected soils are present. Cultivable land in India, at least $12 \mathrm{~m}$ ha is under salty effect and $3.6 \mathrm{~m}$ ha land is under alkali and the rest one is under saline soils.

The rainfed areas of Maharashtra, Andhra Pradesh, Karnataka and Gujarat have minimum $3 \mathrm{~m}$ ha of salt affected soils and almost $1 / 4$ of area is under alkali condition. Mostly these areas are fit for the cotton growing districts of Maharastra (Akola, Amaravati, Buldana, Solapur, Dhule, Ahmednagar, Sangli), Andhra Pradesh (Guntur, Bapatla and other cotton growing district), Karnataka (Bijapur, Dharwad, Gulberga, Raichur), and Gujarat (some of the coastal districts).

\subsection{Waterlogging}

In diverse agro-climatic zones the cotton is grown in India. More than $95 \%$ of crop is irrigated in north. The unnecessary canal irrigation in Rajasthan, Haryana and Punjab, it becomes tough to grow cotton where the water table had climbed to such a high level.

In central India, about $70 \%$ of the crop is grown in rainfed situations where it suffers from waterlogging mostly in early and mid-growth stages. Submerging a dry soil in water creates a motion condition of chemical, physical and biological progressions which greatly affect the soil quality.

Submerging a dry soil finishes the structure of soil by upsetting the masses. The space of the pore is completely filled with water, and the exchange of gas is eradicated in soil and atmosphere. Due to the extreme limit of gaseous exchange in submerging soil which accumulates the hydrogen, $\mathrm{CO}_{2}$ and methane in soil, and depleted the oxygen from atmosphere. The damage or death of a plant is due to the accumulation of above gases in rooting medium and de-oxygenation.

Therefore, the productivity and growth of the plants will be affected. For wa- 
terlogging, cotton has been restricted as susceptible crop. Though, the Frequency and level of any specific response depends on many unified factors such as the cultivar, its age duration and stage of development, depth duration and timing of submerging, and the soil type.

\section{QTL Mapping}

Quantitative trait locus (QTL) investigation is a factual strategy that give two sorts of data genotypic information (normally molecular markers) and phenotypic information (traits measurements) which is utilized to clarify the hereditary premise of variety in complex characteristics [47] [48] [49]. QTL process gives analysts in fields as shifted as agriculture, medication and development to interface certain mind boggling phenotypes to particular locations of chromosomes.

The point of this procedure is to distinguish the activity, number, and interaction of correct location of these zones. Distinctive sorts of markers are utilized, similar to single nucleotide polymorphisms (SNPs), simple sequence repeats (SSRs, or microsatellites), restriction fragment length polymorphisms (RFLPs), and transposable element positions [50] [51] [52].

To finish the QTL examination, the parental strains are crossed, which gives heterozygous (F1) generation and these generations are crossed to use one of various unmistakable plans [53]. Finally, the genotypes and phenotypes of the inferred (F2) populace are scored. Markers that are genetically associated with a QTL exhibits the trait of interest will confine more ordinarily with traits values (large or small egg size); however separated markers won't show huge relationship with phenotype.

Assume, for instance, a characteristic which is controlled by four genes, where the upper alleles increment the estimation of the trait and the lower alleles diminish the estimation of the trait. Additionally, if the alleles of the four genes have same impacts, individuals with the AABBccdd and aabbCDD genotypes may have generally a similar phenotype. However, the offspring (AaBbCcDd) from a backcross of an $\mathrm{F}_{1}$ individual with each parent, would be inconstant.

From backcross progeny, F2 would have somewhere in the range of four to eight upper alleles that would have somewhere in the range of zero to eight capitalized alleles.

The chief purpose of QTL examination, paying little heed to whether the phenotypic differentiations are basically a result of several loci with really enormous effects, or to various loci, each one with minute effects. It appears that an impressive extent of the phenotypic variety in numerous quantitative characteristics can be clarified with couple of loci of huge impact, and the rest one because of various loci of little effect [54] [55].

Genetic maps are moreover critical to recognize the qualities that are associated with the declaration of traits. It is a simple procedure for straightforward heritable characteristics in view of one gene, but on the other hand is feasible for 
complex traits that depend on more qualities. In the last procedure, the expansive isolating populaces $(\mathrm{n}>100)$ are required to fix the quantity of loci connected with the trait [56].

In cotton, the effect of new markers to produce a more immersed Upland cotton linkage guide will build our comprehension of its genetics and moreover extends the cotton raising effectiveness, especially when quantitative characteristics are related.

Generally, agronomic basic characteristics of harvests are acquired quantitatively and are under the results of both nature and the genetic factors controlled by QTL [57].

\section{QTL Mapping for Trait}

Due to the convenience of molecular markers has provided the diverse markers proper for use in cotton research. Maps of G. hirsutum were also made for intraspecific characters [58].

Many studies have been accomplished on intraspecific and interspecific populations in upland cotton, few have been performed in G. barbadense. To define the genetic basis of economic traits of $\mathrm{G}$ barbadense, a broad genetic map including SSRs, EST-SSRs and SRAPs for yield and yield constituents-containing seed index (SI), lint yield (LY), lint index (LI), seed cotton yield and number of seeds per boll. Attached with polymerase chain reaction-based markers, theses markers are economic, efficient and easy to handle, QTL mapping of yield and yield constituents would give an advantage to marker assisted selection, map-based cloning, and yield operations.

QTL mapping in cotton was firstly reported in 1996. However, QTL mapping was not dependable because of the mainframe coding errors in the data. On the basis, of genetic map 31 association groups was built by [59] in QTL Maper software, 100 QTLs were identified by means of mixed linear model.

\section{QTL Analysis for Fiber Traits}

The fiber length, seed index, strength, elongation percent uniformity ratio, and short fiber index was assessed for diploid mapping population consisting of 92 F2 individuals.

QTL analysis was carried out through interval and composite interval mapping in QTL Cartographer 2.5, by the linkage map and phenotypic information, [60].

The Composite interval mapping (CIM) was performed by the Zmapqtl component of Cartographer [61]. The analysis was carried out with five background markers which is based on the forward-backward regression method of selection.

The evaluation which is given by (Zmapqtl) for the square of the partial correlation coefficient (R2) for additive and the dominant effect. In the present investigation, LOD threshold of $\geq 2.5$ ( 1000 permutations) was used to declare sig- 
nificant QTLs.

\section{Fiber Strength}

There are three QTLs were noticed for FS, of which two QTLs were situated on A02 and exhibited strong over dominance. The GB allele at qFSchr23 and qFSA02a was linked with reduced FS, and that at qFSA02a was the reverse. The QTLs ranged from $15.26 \%$ for qFSA02b to $37.12 \%$ for qFSA02a explained the percentage of phenotypic variation.

\section{Marker-Assisted Selection}

Definition: The use of DNA markers that are tightly linked to target loci as an extra or to assist phenotypic screening.

MAS is a combined product of traditional genetics and molecular biology. In genomics MAS is also known as a form of biotechnology which is used for genetic finger printing technique, a benefit to plant breeders in matching molecular profile to the physical properties of the cultivar. It's an identification of DNA sequences situated near the genes that can be followed to breed for traits that are difficult to detect [62].

MAS raises the use of DNA markers that are tightly associated to the target loci as an additional or to support phenotype screening. An allele is determined as a DNA marker; the plants that have specific genes or quantitative trait loci (QTL) may be known on their genotype rather than their phenotype. [63] described the fundamental advantages of MAS which are: 1) Being simpler associated to phenotypic breeding; 2) Selection may be passed out at breeding stage and single plants may be selected with high reliability.

In this technique, linkages are needed among DNA markers and agronomic significant traits such as, tolerance to biotic stresses, insects and nematodes, resistance to pathogens, quality parameters and quantitative traits.

MAS in comparison to genetic engineering includes the artificial insertion of such individual genes from one organism into the genetic material of another naturally, but not completely from other unrelated species [64].

In traditional methods of breeding, the plants express new desired traits, like bigger potatoes or sweeter strawberries, which are selected from crosses of a wide range of strawberries or potatoes.

As simple traits such as sugar content or size can simply be measured, further more complex traits such as drought resistance or disease are much more difficult for the breeder to see when selecting plants which are expressing those traits from a large pool of plants.

For example, as breeder it is difficult to identify those potatoes that are more drought-resistant than others. Marker-assisted selection (MAS), is also called marker-assisted breeding (MAB), to avoid this problem by applying genetic markers that are connected to the desired trait. When they are capable to identify a genetic sequence which is permanently connected to the disease resistance 
i.e. for complicated traits, the testing of every single offspring plant avoided-for rapid DNA marker, they just need to look on testing, and instantly they know which plants have the trait and which do not.

In traditional breeding, no DNA is altered and no new gene introduced during this process. MAS is also known as SMART breeding, which stands for Selection with Markers and Advanced Reproductive Technology. As compared to phenotypic selection, MAS is more effective, efficient and reliable. In MAS the complex breeding traits are not feasible from conventional methods. While certainly not the golden bullet for all problems, MAS is gives an approach to conventional plant breeding.

"By the use of traditional approaches, the breeding goals cannot be achieved, for developing a new cultivar; there is a significant role of molecular markers." [65] "Marker-assisted selection plays a vital role in revolutionising the plant breeding disciplines." [66] "The most influential tools in the emerging biotechnology are marker-assisted breeding." [67] By the activity of thousand genes that is obtained from given plant varieties and their interactions with cultural practices and environmental conditions [68]. For desirable performance under given environmental conditions and cultural practices is the basic element of plant breeding which depends on the selection of plant varieties [63].

\subsection{Types of Markers}

There are two types of markers.

1) Linked markers

2) Direct markers

\subsection{Linked Markers}

Single type of molecular marker is called a linked marker. Scientists applying well-designed experiments to find out the molecular markers that are situated close to main genes of interest.

Linked markers are not part of the DNA of the gene and these are present only near the gene of interest on the chromosome. Scientists are trying to discover a certain gene in an animal species.

Selecting animals casually from a population and studying them would give the scientists no signs, whether a marker is linked with the gene. Though, if they studied the progeny of animals through many generations, they might be able to fix the presence of a suitable molecular marker.

\subsection{Direct Markers}

Another form of molecular marker is one that is part of the gene of interest. To work with direct markers is easy after they are found, but they frequently very hard to find than linked markers.

In Southern blotting technique a porous membrane is used to contain specific radioactive DNA probes for one or more DNA fragments. The short pieces of 
DNA is known as probes, these are used to find the specific sequences of $A, G, T$, and $\mathrm{C}$ in long pieces of DNA from a chromosome. On an electrophoresis gel at a unique DNA band the probes are hybridizes to the membrane.

MAS is more proficient than choice in light of phenotype.

Assume assessment is:

- Time overwhelming

- Not easy

- Expensive

- Performed off season

- If used for: Gene pyramiding

- Early stages of development

- Several selections simultaneously

- Small in heritability traits

Technologies used for molecular markers are: restriction fragment length polymorphisms, simple sequence repeats, and single nucleotide polymorphisms.

\subsubsection{Restriction Fragment Length Polymorphisms (RFLPs)}

RFLPs were firstly used as molecular markers to identify genetic variability in organisms. In (RFLP) restriction enzymes are used to cut the DNA molecule and recognize regions linked to a trait. The fragments of DNA generated from one restriction enzyme digest can be in the millions, through numerous being several thousand nucleotides long.

It is difficult to fix specific DNA fragments that are linked with the trait of interest on an electrophoresis gel. Southern blotting technique was developed, to visualize the specific DNA fragments, for one or more DNA fragments a porous membrane holding a specific radioactive DNA probes used in Southern blotting.

To find specific sequences of $A, C, T$, and $G$ the probes are used in a very short piece of DNA, from long pieces of DNA in chromosome. On an electrophoresis gel, the probe attached to the membrane at a unique DNA band. On $\mathrm{X}$-ray film, the probe is developed containing the membrane which can be analysed.

\subsubsection{Simple Sequence Repeats or Microsatellites}

Simple sequence repeats (SSRs), also called microsatellites, are repeated units of two to six nucleotides that occur throughout an organism's genome.

SSRs are also called microsatellites; it's a repeating unit of two to six nucleotides that occur in an organism's genome. For example TATATATAT is one of a microsatellite. Like GATGATGAT is another example.

SSRs are highly polymorphic (have many forms) and very useful as molecular markers. In a wide range of analysis (SSRs) have been used successfully as markers, mostly those involving disease diagnosis and forensics.

\subsubsection{Single Nucleotide Polymorphisms (SNPs)}

On regular basis, SNPs will occur in an organism's DNA more than $1 \%$ of the 
time. For DNA proteins codes in an organism only about 3\% to 5\%, most SNPs are found outside the regions of genes of interest.

Because of researchers actual interest, SNPs are found in a gene of interest which is straightly associated with a desired trait. The recent advancement in technology, SNPs are playing a larger role in selection and diagnosis of genetic traits.

\subsection{Advantages of Molecular Markers}

The researchers tried to test the molecular markers for a particular trait as early as the embryo stage in animals or in the seeds of plants before they are planted. Now in that time, there is no need for the organism to grow a stage at which the trait can be observed, wait in some cases can take many years.

For example, in a single cross, generally the procedure is: to select the parent plants and cross them, at least one time keeps the DNA marker allele(s) for the desired trait of interest.

1) Plants from F1 population and identify the existence of the marker alleles to remove false hybrids.

2) Plants from segregating F2 population, separate individuals for the marker(s), and harvest the individuals carrying the desired marker allele(s).

3) Plant from F3 population, separate individual plants with the marker(s). The majority of F3 individuals in a plant row can be used for the marker screening.

\subsection{Importance of MAS}

In revolutionizing, impacting, marker assisted selection (MAS) played a vital role. The use of MAS in breeding programs for product development as a tool in breeding schemes for many agricultural important crops, containing grain, oilseeds, vegetables, ornamentals, and tree crops.

The levels of efficiency in selection at early generations and classification in later generations are the actual deliverables from MAS. To build a setup of a high throughput MAS program is expensive and time consuming method, with vision and patience required.

Mostly, traditional breeders use one or more methods for selection and screening, in which the use of biochemical markers, morphological traits or by scoring host plant response to the insect pest.

About 80 morphological traits in Gossypium hirsutum have been used, but have very narrow worth in selection and most of these have main effects on other significant quantitative traits. In most of the cases, heterozygous condition is not recognizable.

Identification of morphological traits contains large time and effort for selection, separately from association with undesirable traits, it would be perfect to identify a molecular marker that co-segregate with resistance and can be used for selection and screening. 
Furthermore, molecular markers are new genetic gears with potential to improve selection efficacy, and are beneficial since these have no effect on the phenotype. The availability of molecular markers is vast and also have the benefit to identify the heterozygote.

Mostly, the morphological markers need mature plants and these markers can be used to assess seedlings or any plant part. Hence this allows swift screening of germplasm material. Moreover co-dominance is greatly more common in molecular markers.

Morphological markers are frequently conditioned by two genes but the molecular markers are inherited as single factor loci. Most commonly used biochemical markers like-“isozymes" has consequently far not been known for insect resistance in cotton.

Presently, for the identification of markers the most viable option is RFLPs (Restriction fragment length polymorphism) and PCR (Polymerase chain reaction) based approaches plus RAPDs (Randomly amplified polymorphic DNA) and AFLP (Amplified fragment length polymorphism).

Marker assisted selection for desirable traits could accelerate the introgression of the desirable gene in current cotton cultivars and also desirable plants in a backcross population could be easily selected without screening through biotic or abiotic pressures, by detection of the presence of any coupling markers. In modern cotton cultivars, the introgression of the desirable gene that could accelerate for desirable traits by Marker assisted selection, and without screening through biotic or abiotic pressures, the desired plants could be selected in a backcross population by the detection of any coupling markers.

\section{References}

[1] Multani, D.S. and Lyon, B.R. (1995) Genetic Finger Printing of Australian Cotton Cultivars with RAPD Markers. Genome, 38, 1005-1008. https://doi.org/10.1139/g95-132

[2] Tatineni, V., Cantrell, R.G. and Davis, D.D. (1996) Genetic Diversity in Elite Cotton Germplasm Determined by Morphological Characteristics and RAPDs. Crop Science, 36, 186-192. https://doi.org/10.2135/cropsci1996.0011183X003600010033X

[3] Iqbal, M.J., Aziz, N., Saeed, N.A. and Zafar, Y. (1997) Genetic Diversity Evaluation of Some Elite Cotton Varieties by RAPD Analysis. Theoretical and Applied Genetic, 94, 139-144. https://doi.org/10.1007/s001220050392

[4] Lu, H.J. and Myers, G.O. (2002) Genetic Relationships and Discrimination Often Influential Upland Cotton Varieties Using RAPD Markers. Theoretical and Applied Genetic, 105, 325-331. https://doi.org/10.1007/s00122-002-0947-8

[5] Thirtle, C., Beyers, L., Ismael, Y. and Piesse, J. (2003) Can GM Technologies Help the Poor? The Impact of Bt Cotton in Makhathini Flats, KwaZulu-Natal. World Development, 31, 717-732. https://doi.org/10.1016/S0305-750X(03)00004-4

[6] Qaim, M. and Matuschke, I. (2005) Impacts of Genetically Modified Crops in Developing Countries a Survey. Quarterly Journal of International Agriculture, 44, 207-227.

[7] Bakhsh, K., Hassan, I. and Maqbool, A. (2005) Factors Affecting Cotton Yield: A 
Case Study of Sargodha (Pakistan). Journal of Agriculture and Social Sciences, 1, 332-334.

[8] Mumtaz, A., Chaudhry, I.S. and Khan, M.B. (2009) Factors Affecting Cotton Production in Pakistan: Empirical Evidence from Multan District. MPRA Paper No. 22829.

[9] Liu, S., Saha, S., Stelly, D. and Burr, B. (2000a) Chromosomal Assignment of Microsatellite Loci in Cotton. The Journal of Heredity, 91, 326-332. https://doi.org/10.1093/jhered/91.4.326

[10] Reddy, O.U., Pepper, A.E., Abdurakhmonov, I., Saha, S., Jenkins, J.N., Brooks, T., Bolek, Y. and El-zik, K.M. (2001) New Dinucleotide and Tri-Nucleotide Microsatellite Marker Resources for Cotton Genome Research. Crop Science, 5, 103-113.

[11] Nguyen, T.B., Giband, M., Brottier, P., Risterucci, A.M. and Lacape, J.M. (2004) Wide Coverage of the Tetraploide Cotton Genome Using Newly Developed Microsatellite Markers. Theoretical and Applied Genetic, 109, 167-175.

[12] Fryxell, P.A. (1992) A Revised Taxonomic Interpretation of Gossypium L. (Malvaceae). Rheedea, 2, 108-165.

[13] Wendel, J.F. and Cronn, R.C. (2003) Polyploidy and the Evolutionary History of Cotton. Advances in Agronomy, 78, 140-186.

https://doi.org/10.1016/S0065-2113(02)78004-8

[14] Harlan, J.R. and de Wet, J.M.J. (1971) Toward a Rational Classification of Cultivated Plants. Taxon, 20, 509-517. https://doi.org/10.2307/1218252

[15] IBPGR (1980) Descriptors for Cotton Species in International Board for Plant Genetic Resources Working Group, 1979, Rome.

[16] Percival, A.E. (1987) The National Collection of Gossypiumgermplasm. Southern Cooperative Series Bulletin No. 321.

[17] Toll, J.A. (1995) Processing of Germplasm, Associated Material and Data. In: Guarino, L., Ramanatha, R.V. and Reid, R., Eds., Collecting Plant Genetic Diversity: Technical Guidelines, CABI, Wallingford, 577-595.

[18] Lacape, J.M., Dessauw, D., Rajab, M., Noyer, J.L. and Hau, B. (2007) Microsatellite Diversity in Tetraploid Gossypiumgermplasm: Assembling a Highly Informative Genotyping Set of Cotton SSRs. Molecular Breeding, 19, 45-58. https://doi.org/10.1007/s11032-006-9042-1

[19] Abdalla, A.M., Reddy, O.U.K., El-Zik, K.M. and Pepper, A.E. (2001) Genetic Diversity and Relationships of Diploid and Tetraploid Cottons Revealed Using AFLP. Theoretical and Applied Genetic, 102, 222-229. https://doi.org/10.1007/s001220051639

[20] Hinze, L.L., Dever, J.K. and Percy, R.G. (2012) Molecular Variation among and within Improved Cultivars in the U.S. Cotton Germplasm Collection. Crop Science, 52, 222-223. https://doi.org/10.2135/cropsci2011.04.0202

[21] Percy, R.G. (2009) The Worldwide Gene Pool of Gossypium barbadense L. and Its Improvement. In: Paterson, A., Ed., Genetics and Genomics of Cotton, Springer, Berlin, 53-68. https://doi.org/10.1007/978-0-387-70810-2_3

[22] Wendel, J.F. and Percy, R.G. (1990) Allozyme Diversity and Introgression in the Galapagos-Islands Endemic Gossypiumdarwinii and Its Relationship to Continental Gossypiumbarbadense. Botany Publication and Papers, 10.

[23] Hinze, L.L. (2015) Nondestructive Measurements of Cotton seed Nutritional Trait Diversity in the US National Cottongermplasm Collection. Crop Science, 55, 770-782. https://doi.org/10.2135/cropsci2014.04.0318 
[24] Morgante, M., Hanafey, M. and Powell, W. (2002) Microsatellites Are Preferentially Associated with Nonrepetitive DNA in Plant Genomes. Nature Genetics, 30, 194-204. https://doi.org/10.1038/ng822

[25] Turkoglu, Z., Bilgener, S., Ercisli, S. and Bakir, M. (2010) Simple Sequence Repeat-Based Assessment of Genetic Relationships among Prunus Rootstocks. Genetics and Molecular Research, 9, 2156-2165. https://doi.org/10.4238/vol9-4gmr957

[26] Salam, A. (2008) Production, Prices and Emerging Challenges in the Pakistan Cotton Sector. In: Cororaton, C.B., et al., Eds., Cotton-Textile-Apparel Sectors of Pakistan: Situation and Challenges Faced, IFPRI Discussion Paper 00800, Washington DC.

[27] Byerlee, D., Hobbs, P.R., Khan, B.R., Majid, A., Akhtar, M.R. and Hashmi, N.I. (1986) Increasing Wheat Productivity in the Context of Pakistan's Irrigated Cropping Systems. National Agricultural Research Center (NARC), Islamabad, PARC/CIMMYT, Paper 86-7.

[28] Iqbal, M., Azeem, M. and Ahmad, M. (2001) Determinants of Higher Wheat Productivity in Irrigated Pakistan. The Pakistan Development Review, 40, 753-765.

[29] Wu, C.C. (1977) Education in Farm Production. The Case of Taiwan. American Journal of Agricultural Economics, 59, 7-33. https://doi.org/10.2307/1239397

[30] Dhakal, D., Grabowski, R. and Belbase, K. (1989) The Effect of Education in Nepal's Traditional Agriculture. Economics of Education Review, 6, 27-34. https://doi.org/10.1016/0272-7757(87)90030-6

[31] Ahuja, S.L., Dhayal, L.S. and Prakash, R. (2006) A Correlation and Path Coefficient Analysis of Components in G. hirsutum L. Usual and Fiber Quality Grouping. Turkish Journal of Agriculture and Forestry, 30, 317-324.

[32] Farooq, J., Anwar, M., Riaz, M., Mehmood, A., Farooq, A. and Iqbal, M.S. (2013) Association and Path Analysis of Earliness Yield and Fiber Related Traits under Cotton Leaf Curl Virus (CLCuV) Intensive Conditions in G. hirsutum L. Plant Knowledge Journal, 2, 43-50.

[33] Ahmad, W., Khan, N.U., Khalil, M.R., Parveen, A., Aimen, U., Saeed, S.M. and Shah, S.A. (2008) Genetic Variability and Correlation Analysis in Upland Cotton. Sarhad Journal of Agriculture, 24, 573-580.

[34] Arshad, M., Hanif, M., Ilahi, N. and Shah, S.M. (1993) Correlation Studies on Some Commercial Cotton Varieties of G. hirsutum. Sarhad Journal of Agriculture, 9, 49-53.

[35] Iqbal, M., Chang, M.A., Iqbal, M.Z., Hassan, M.U., Nasir, A. and Islam, N.U. (2003) Correlation and Path Coefficient Analysis of Earliness and Agronomic Characters of Upland Cotton in Multan. Pakistan Journal of Agronomy, 2, 160-168. https://doi.org/10.3923/ja.2003.160.168

[36] Khan, N.U. (2003) Genetic Analysis, Combining Ability and Heterotic Studies for Yield, Its Components, Fibre and Oil Quality Traits in Upland Cotton (G. hirsutum). PhD Dissertation, Sindh Agricultural University Tandojam, Sindh.

[37] Stockton, J.R., Doneen, L.D. and Walhood, V.T. (1961) Boll Shedding and Growth of the Cotton Plant in Relation to Irrigation Frequency. Agronomy Journal, 53, 272-275. https://doi.org/10.2134/agronj1961.00021962005300040020x

[38] Gerik, T.J., Faver, K.L., Thaxton, P.M. and El-Zik, K.M. (1996) Late Season Water Stress in Cotton: I. Plant Growth, Water Use and Yield. Crop Science, 36, 914-921. https://doi.org/10.2135/cropsci1996.0011183X003600040017x

[39] Hsiao, T.C. (1973) Plant Responses to Water Stress. Annual Review of Plant Physi- 
ology, 24, 519-570. https://doi.org/10.1146/annurev.pp.24.060173.002511

[40] Grimes, D.W., Dickens, W.L. and Anderson, W.D. (1969) Functions for Cotton (Gossypium hirsutum L.) Production from Irrigation and Nitrogen Fertilization Variables. II. Yield Components and Quality Characteristics. Agronomy Journal, 61, 773-776. https://doi.org/10.2134/agronj1969.00021962006100050036x

[41] Ritchie, G.L., Whitaker, J.R., Bednarz, C.W. and Hook, J.E. (2009) Subsurface Drip and Overhead Irrigation of Cotton: A Comparison of Plant Boll Distribution in Upland Cotton. Agronomy Journal, 101, 1336-1344. https://doi.org/10.2134/agronj2009.0075

[42] McMichael, B.L., Jordan, W.R. and Powell, R.D. (1973) Abscission Processes in Cotton: Induction by Plant Water Deficit. Agronomy Journal, 65, 202-204. https://doi.org/10.2134/agronj1973.00021962006500020005x

[43] Saini, H.S. and Westgate, M.E. (2000) Reproductive Development in Graincrops during Drought. Advances in Agronomy, 68, 59-96. https://doi.org/10.1016/S0065-2113(08)60843-3

[44] Bennett, M.D., Finch, R.A. and Barclay, I.R. (1976) The Time, Rate and Mechanism of Chromosome Elimination in Hordeum Hybrids. Chromosoma, 54, 175-200. https://doi.org/10.1007/BF00292839

[45] Dhindsa, R.S., Beasley, C.A. and Ting, I.P. (1975) Osmoregulation in Cotton Fiber: Accumulation of Potassium and Malate during Growth. Plant Physiology, 56, 394-398.

[46] Marani, A. and Amirav, A. (1971) Effects of Soil Moisture Stress on Two Varieties of Upland Cotton in Israel. The Coastal Plain Region. Experimental Agriculture, 7, 213-224. https://doi.org/10.1017/S0014479700000302

[47] Falconer, D.S. and Mackay, T.F.C. (1996) Introduction to Quantitative Genetics. 4th Edition, Prentice Hall, London.

[48] Kearsey, M.J. and Farquhar, A.G.L. (1998) QTL Analysis in Plants: Where Are We Now? Heredity, 80, 13-142. https://doi.org/10.1046/j.1365-2540.1998.00500.x

[49] Lynch, M. and Walsh, B. (1998) Genetics and Analysis of Quantitative Traits. Sinnauer Associates Inc., Sunderland.

[50] Vignal, A. (2002) A Review on SNP and Other Types of Molecular Markers and Their Use in Animal Genetics. Genetics Selection Evolution, 34, 275-305. https://doi.org/10.1186/1297-9686-34-3-275

[51] Gupta, P.K. and Rustgi, S. (2004) Molecular Markers from the Transcribed/Expressed Region of the Genome in Higher Plants. Functional and Integrative Genomics, 4, 139-162. https://doi.org/10.1007/s10142-004-0107-0

[52] Henry, R.J. (2006) Plant Conservation Genetics. Haworth Press, New York.

[53] Darvasi, A. (1998) Experimental Strategies for the Genetic Dissection of Complex Traits in Animal Models. Nature Genetics, 18, 19-24. https://doi.org/10.1038/ng0198-19

[54] Remington, D.L. and Purugganan, M.D. (2003) Candidate Genes, Quantitative Trait Loci, and Functional Trait Evolution in Plants. International Journal of Plant Sciences, 164, 7-20. https://doi.org/10.1086/367812

[55] Roff, D.A. (2007) A Centennial Celebration for Quantitative Genetics. Evolution, 61, 1017-1032. https://doi.org/10.1111/j.1558-5646.2007.00100.x

[56] Jeuken, M., Wijk, V., Peleman, J. and Lindhout (2001) An Integrated Interspecific AFLP Map of Lettuce (Lactuca) Based on Two L. sativa L. saligna F2 Populations. 
Theoretical and Applied Genetics, 103, 638-647. https://doi.org/10.1007/s001220100657

[57] Geldermann, H. (1975) Investigations on Inheritance of Quantitative Characters in Animals by Gene Markers Methods. Theoretical and Applied Genetics, 46, 319-330. https://doi.org/10.1007/BF00281673

[58] Zhang, J., Lu, Y., Cantrell, R.G. and Hughs, E. (2005) Molecular Marker Diversity and Field Performance in Commercial Cotton Cultivars Evaluated in the South Western USA. Crop Science, 45, 1483-1490. https://doi.org/10.2135/cropsci2004.0581

[59] Shappley, Z.W., Jenkins, J.N., Watson, C.E., Kahler, A.L. and Meredith, W.R. (1996b) Establishment of Molecular Markers and Linkage Groups in Two F2 Populations of Upland Cotton. Theoretical and Applied Genetics, 92, 915-919. https://doi.org/10.1007/BF00224030

[60] Basten, C.J., Weir, B.S. and Zeng, Z.B. (2007) QTL Cartographer 2.5: A Reference Manual and Tutorial for QTL Mapping. Department of Statistics, North Carolina State University, Raleigh.

[61] Zeng, Z.B. and Weir, B.S. (1996) Statistical Methods for Mapping Quantitative Trait Loci. Acta Agronomica Sinica, 22, 535-549.

[62] Berloo, R.V. and Stam, P. (1999) Comparison between Marker-Assisted Selection and Phonotypical Selection in a Set of Arabidopsis thaliana Recombinant Inbred Lines. Theoretical and Applied Genetics, 98, 113-118. https://doi.org/10.1007/s001220051047

[63] Collard, B.C.Y. and Mackill, D.J. (2008) Marker-Assisted Selection an Approach for Precision Plant Breeding in the Twenty-First Century. Philosophical Transactions of the Royal Society B, Biological Sciences, 363, 557-572. https://doi.org/10.1098/rstb.2007.2170

[64] Jonah, P.M., Bello, L.L., Lucky, O., Midau, A. and Moruppa, S.M. (2011) The Importance of Molecular Markers in Plant Breeding Programmes. Global Journal of Science Frontier Research, 11, 4-12.

[65] Peleman, J.D. and van Der Voort, J.R. (2003) The Challenges in Marker Assisted Breeding. In: van Hintum, Th.J.L., Lebeda, A., Pink, D. and Schut, J.W., Eds., Eucarpia Leafy Vegetables, CGN, 125-130.

[66] Cahill, D.J. and Schmidt, D.H. (2004) Use of Marker Assisted Selection in a Product Development Breeding Program. Proceedings of the 4th International Crop Science Congress, Brisbane, 26 September-1 October 2004. http://www.cropscience.org.au/icsc2004/

[67] Naylor, R. and Manning, R. (2005) Unleashing the Genius of the Genome to Feed the Developing World. Proceedings of the American Philosophical Society, 149, 515-528.

[68] Collins, N.C., Tardieu, F. and Tuberosa, R. (2008) Quantitative Trait Loci and Crop Performance under Abiotic Stress: Where Do We Stand? Plant Physiology, 147, 469-486. https://doi.org/10.1104/pp.108.118117

\section{Abbreviations}

QTL (quantitative trait locus), MAS (marker assisted selection), RFLP (restriction fragment length polymorphism), SSR (simple sequence repeat), SNP (single nucleotide polymorphism). 